\title{
ОСОБЛИВОСТІ МАРКЕТИНГОВОЇ ПОЛІТИКИ ВИЩОГО НАВЧАЛЬНОГО ЗАКЛАДУ В УМОВАХ КРЕДИТНО-МОДУЛЬНОЇ СИСТЕМИ ОРГАНІЗАЦІЇ НАВЧАЛЬНОГО ПРОЦЕСУ
}

\author{
В. М. Ждан, В. М. Бобирьов, С. М. Білаш, М. М. Рябушко, Т. В. Шарбенко \\ Вищий державний навчальний заклад Украӥни "Украӥнська медична стоматологічна академія"
}

\section{PECULIARITIES OF MARKETING POLICY OF HIGHER EDUCATIONAL INSTITUTION IN THE CONDITIONS OF CREDIT-MODULAR SYSTEM OF ORGANIZATION OF EDUCATIONAL PROCESS}

\author{
V. M. Zhdan, V. M. Bobyriov, S. M. Bilash, M. M. Riabushko, T. V. Sharbenko \\ Higher State Educational Institution of Ukraine "Ukrainian Medical Stomatological Academy”
}

\begin{abstract}
У статті вказано на необхідність впровадження сучасних маркетингових технологій в освітній процес та ознайомлення потенційних абітуріснтів з особливостями кредитно-модульної системи організації навчального процесу.
\end{abstract}

The article pointed out the necessity of implementation of modern marketing technoloqies in educational process and acquaintance of potential university entrants with peculiarities of credit-modular system of educational process organization.

Вступ. Розвиток української медичної освіти, що спрямовується на підготовку перш за все висококваліфікованого лікаря, який відповідає сучасному рівню розвитку медичної науки і вимогам суспільства, грунтується на введенні якісно нової методології організації навчального процесу за європейським зразком: в основу концепції покладені європейські тенденції (кредитно-модульна система організації навчального процесу) та національна стратегія розвитку вищої медичної освіти в Україні.

Основна частина. Інтенсивний розвиток ринку вищої та спеціальної освіти в Україні останнім часом супроводжується зростом рекламно-інформаційної активності у сфері популяризації діяльності вузів. Ми стоїмо на розуміння того, що реклама вузу повинна бути максимально об' єктивною, достовірною, інформаційно насиченою, етичною та характеризуватись високим ступенем маркетингових технологій, які будуть зрозумілими пересічному громадянинові. Цього вимагає і сам предмет реклами, адже явні помилки, або неточності в тексті, який рекламує вищий навчальний заклад, підриває довіру до нього. Рекламу вузу взагалі необхідно вважати зоною підвищеної соціальної відповідальності перед аудиторією, і в першу чергу, перед випускниками та їх батьками.

В умовах розвитку сучасного суспільства проблема якості вищої медичної освіти значно ускладнюєть- ся. Реформування сфери вищої медичної освіти спрямовуються саме на пошук комплексного, системного підходу, реалізація якого можлива тільки в межах системи управління якістю. Адже особливого значення сьогодні набуває проблема пошуку оптимальної моделі державного управління якістю вищої медичної освіти в Україні. Управління процесами і трансформаціями в системі галузевої стандартизації вищої медичної освіти як у структурному, так і в функціональному плані є частиною загального управлінського поля і разом з тим має внутрішні галузеві функціональні структури [1-3].

Система галузевої стандартизації є полем взаємодії:

· системи охорони здоров’я, з її основним об'єктом - людиною, як пацієнтом;

· системи вищої медичної освіти, з її основним об'єктом - майбутнім фахівцем в галузі охорони здоров'я;

- системи матеріально-інформаційного забезпечення процесу стандартизації, як інструментом взаємодії.

Методологічно важливим підгрунтям для аналізу та оцінки рекламної продукції вищого навчального закладу є розуміння того, якою повинна бути ця реклама за своїм типом. На нашу думку, реклама вищого медичного навчального закладу повинна мати більшою мірою іміджевий, аніж суто комерційний 
характер. Сама рекламна практика підтверджує те, що відкрита комерційна реклама конкретних послуг з багаторазовим повторюванням у засобах масової інформації ефективніша, якщо послуги підносяться як такі, що мають відносно не високу вартість. В даному випадку вища медична освіта - це товар, який “набувається” конкретною людиною нечасто i може бути порівняна з рекламою банків, послугами яких користуються усе життя. Тому реклама медичних вищих закладів повинна бути максимально інформативною, комплексною, розрахованою на формування довіри, яка має об’єктивний характер, що створює враження повноти та відкритості.

32005 р. в Україні вища медична освіта надається відповідно до положень Болонської декларації, за кредитно-модульною системою. На сьогодні ми можемо відзначити кілька проблемних моментів у даній cфepi:

- неповна відповідність стандартам освітнього простору Свропейського Союзу та системи вищої медичної (фармацевтичної) освіти України;

- зниження якості підготовки медичних кадрів в результаті низької мотивації студентів та викладачів до самовдосконалення;

• відсутність університетських клінік;

- застосування застарілих педагогічних методик та технологій;

• низький рівень соціального захисту викладача та студента.

До цього ми можемо додати елементарне нерозуміння деякими викладачами та суспільством завдань та цілей євроінтеграції, недосконалість законодавчої бази, низький рівень фінансування вищої школи. Необхідно також чітко усвідомлювати і перспективу зниження абітурієнтського набору, що є результатом як економічної, так і демографічної кризи першої половини 90-х років ХХ століття.

3 метою популяризації вищої медичної освіти у ВДНЗУ "Українська медична стоматологічна академія” розроблено і впроваджується пілотний со- ціальний проект “Новітня медична освіта обличчям до людей”, який проходить під девізом “Здоров’ я нації в руки висококваліфікованих фахівців".

Основна мета проекту - донести інформацію про особливості отримання вищої медичної освіти та професії лікаря в ВДНЗУ “УМСА”, використовуючи сучасні рекламні технології та маркетингові ресурси. У якості основної території реалізації проекту ми розглядаємо 25 районів Полтавської області, включаючи 5 міст обласного значення (Кременчук, Комсомольськ, Миргород, Лубни, Полтава).

Соціологічні дослідження, проведені у середовищі випускників 2011-2012 років, показують, що значна їх частина, а це близько 60 \% опитаних респондентів, або взагалі не володіють точною інформацією про вищі навчальні заклади, або мають їі у зміфологізованому вигляді, що швидше відштовхує, аніж приваблює абітурієнта. I якщо в Полтаві випускники шкіл мають змогу отримати необхідні для них дані, то абітурієнти шкіл районних та сільських у такій можливості обмежені. Тому нами розроблено комплекс заходів, які повинні донести до випускників та їх батьків інформацію про ВДНЗУ "Українська медична стоматологічна академія".

Серед основних концептуальних моментів проекту необхідно відзначити:

- ознайомлення населення та учнів-випускників з особливостями реформування вищої медичної освіти;

- особливості впровадження Болонських дескрипторів в українському освітньому просторі;

- впровадження кредитно-модульної системи у навчальний процес ВДНЗУ "УМСА".

Висновки. На сучасному етапі реформування вищої медичної освіти в державі постає нагальна потреба упровадження сучасних маркетингових технологій в освітній процес та ознайомлення потенційних абітурієнтів з особливостями кредитно-модульної системи організації навчального процесу, з метою якіснішого набору студентів для їх подалышого навчання.

2. Birnbaum R. Managment Fads in Higher Education Where They Come, What They Do, Why They Fail / R. Birnbaum// San Francisco. -2000. - P. 91-157.

3. Концепція реформування системи підготовки лікарів в Україні // Ваше здоров’я. - 2005. - № 22. 